\title{
PENGARUH METODE BERMAIN PERAN TERHADAP PENINGKATAN PERCAYA DIRI PADA ANAK USIA PRA SEKOLAH (4-5 TAHUN) DI PENDIDIKAN ANAK USIA DINI INSAN HARAPAN KLATEN
}

\author{
Rafida Wahyu Tri Utami ${ }^{1}$, Moh Hanafi ${ }^{2}$, Pramono Giri Kriswoyo² \\ ${ }^{1}$ Mahasiswa Program Studi D IV Keperawatan Magelang Poltekkes Kemenkes Semarang \\ 2Dosen Program Studi D IV Keperawatan Magelang Poltekkes Kemenkes Semarang \\ Email: rafida.paraf18@gmail.com
}

\begin{abstract}
Roleplay metode is one of ways to increase self esteem in in preschool children. The lesson of pre school children ( $4-5$ years old) is the most basic lesson, it means it's a critical range to the next step. Roleplay has an education character. The aims of this study were to find any influence of roleplay to increase self esteem in pre school children. This method was pre experimental with one group pre test post test design. The analysis in this study used Wilcoxon test. The sample were 20 person who has age between 4-5 years old. The result shows that after finished the roleplay, children who has high self esteem 12 person $(60 \%)$ is more than children who has moderate self esteem 8 person $(40 \%)$. The result shows $p$ value 0,000 before and after role play. It means there is a difference betwen self esteem before and after do a roleplay.It concluded there's a significant influenc between roleplay metode to increase self esteem in pre school children (4-5 years old) Insan harapan at klaten.
\end{abstract}

Keywords : Roleplay metode, self esteem, pre school

\begin{abstract}
ABSTRAK
Metode bermain peran adalah salah satu cara untuk meningkatkan rasa percaya diri pada anak usia pra sekolah. Pendidikan usia pra sekolah (4-5 tahun) merupakan pendidikan paling mendasar, hal ini merupakan rentang kritis untuk tahapan selanjutnya. Bermain peran atau disebut pura-pura mempunyai sifat edukatif. Penelitian ini bertujuan untuk mengetahui pengaruh bermain peran terhadap peningkatan percaya diri sebelum dan sesudah dilakukan bermain peran. Penelitian ini menggunakan metode Pra Eksperimen dengan one group pre test post test. Sasaran penelitian adalah anak pra sekolah yang berusia 4-5 tahun Insan Harapan di Klaten. Jumlah sampel sebanyak 20 orang. Analisis statistic yang digunakan adalah uji Wilcoxon. Hasil yang penelitian ini yaitu setelah dilakukan tindakan bermain peran anak yang memiliki percaya diri tinggi lebih banyak yaitu 12 anak (60\%), dan anak percaya diri sedang yaitu 8 anak (40\%). Hasil penelitian diperoleh $p$ value $=0,000$ artinya ada perbedaan bermakna rasa percaya diri sebelum dan sesudah dilakukan bermain peran. Hasil penelitian menunjukkan pengaruh yang signifikan antara bermain peran dengan peningkatan rasa percaya diri pada anak usia pra sekolah (4-5 tahun) pendidikan anak usia dini di Insan Harapan Klaten.
\end{abstract}

Kata Kunci: Metode bermain peran, percaya diri, pra sekolah 


\section{PENDAHULUAN}

Pada zaman sekarang ini banyak orang tua menginginkan anak yang memiliki keunggulan prestasi di bidang akademik dan rela membayar mahal demi pendidikan supaya memiliki keunggulan intelektual. Bahkan banyak anggapan bahwa dengan menyekolahkan sedini mungkin di sekolah yang cenderung lebih mementingkan bidang akademis akan membuat cepat pintar.

Kegiatan bermain yang dilakukan terkadang dianggap biasa saja, orang tua menganggap belajar itu dengan menghafal, membaca atau menulis. Bahkan masih banyak ditemukan pendidik untuk mengenalkan angka dan huruf. Hal tersebut bertentanggan dengan prinsip Developmentally Appropriate Practice (DAP). Alasannya karena beberapa Sekolah Dasar mensyaratkan agar calon peserta didiknya harus sudah bisa membaca (Obidike, 2013).

Banyak yang menganggap jika masa sekolah diawali dari formal saat kelas satu. Anggapan tersebut tidak hanya dianut oleh satu atau dua orang saja tetapi banyak orang, bahkan menjadi kebiasaan yang hingga kini masih banyak dilakukan. Alhasil lima tahun pertama berlalu begitu saja tanpa pemberian stimulasi yang optimal (Novan, 2016).

Undang-Undang Nomor 20 Tahun 2003 tentang Sistem Pendidikan Nasional disebutkan bahwa pendididkan usaha sadar dan terencana untuk mewujudkan suasana belajar dan proses pembelajaran agar peserta didik secara aktif dapat megembangkan potensi dirinya untuk memiliki kekuatan mulia serta ketrampilan yang diperlukan untuk diri sendiri, masyarakat, bangsa dan negara.

Peraturan Pemerintahan Nomor 17 Tahun 2010 tentang Pengelolaan dan Penyelenggaraan Layanan Pendidikan disebutkan bahwa pendidikan pra sekolah yaitu Pendidikan Anak Usia Dini (PAUD) berfungsi untuk membina, menumbuhkan, mengembangkan seluruh potensinya secara optimal serta memberikan kesempatan untuk menikmati masa kanak-kanak sehingga terbentuk perilaku dan kemampuan dasar sesuai dengan perkembangan untuk kesiapan memasuki jenjang pendidikan selanjutnya.

Pendidikan usia pra sekolah merupakan pendidikan paling mendasar, hal ini merupakan rentang kritis untuk tahapan selanjutnya. Masa usia 3 sampai 6 tahun adalah fase bermain, dalam fase ini mulai belajar berfantasi, berfikir lebih kreatif dan mulai menjalin hubungan pertemanan untuk saling berbagi, maupun memberi dukungan. Melalui kegiatan tersebut dapat mempelajari banyak hal penting yang dapat ditumbuhkan secara optimal (Diana, 2015).

Berdasarkan data yang diperoleh di Insan Harapan Klaten terdapat 50 anak yang terdiri dari 14 laki-laki dan 36 perempuan, namun hanya 20 orang yang memiliki percaya diri yang rendah diantaranya 4 laki-laki dan 16 perempuan. Hasil wawancara dengan kepala mengatakan masih banyak yang belum mempunyai rasa percaya diri yang tinggi. Kepercayaan diri yang rendah dibuktikan pada diberikan tugas atau sedang mengikuti kegiatan yang diberikan guru berkata tidak bisa atau bahkan menangis, bahkan ada beberapa yang kurang bergaul dengan temantemannya. Mereka hanya menjadi 
penonton pada saat temannya bermain tidak bergabung untuk bermain bersama dan masih cenderung pasif dalam melakukan kegiatan.

Rendahnya percaya diri terkadang menghambat pencapaian prestasi, karena anak mempunyai perasaan takut salah dalam mengerjakan tugas yang telah diberikan oleh guru bahkan meminta bantuan temannya untuk mengerjakan tugasnya karena kurang percaya dengan kemampuan diri yang telah dimiliki. Orang tua mempunyai harapan besar kepada anak agar tumbuh dengan rasa percaya diri yang tinggi dengan merasa yakin akan kemampuan diri sendiri dan tidak bergantung kepada orang lain. Berbagai kelemahan pribadi menjadi sumber penurunan dan mempengaruhi tingkat kepercayaan diri, antara lain kelainan fisik, sering mengalami kegagalan, kalah dalam bersaing, tidak siap menghadapi permasalahan yang ada, tidak mudah beradaptasi dengan lingkungan sekitar, mudah menyerah, tidak pandai dalam menarik simpati orang. Pola asuh orang tua yang salah juga menyebabkan percaya diri menurun, anak menjadi memiliki sikap ragu-ragu, ada rasa ketakutan mengulangi kesalahan dan dimarahi oleh orang tua dalam mengerjakan tugas yang diberikan.

Cara untuk meningkatkan rasa percaya diri adalah bermain aktif tetapi juga mempunyai sifat edukatif yang bermanfaat untuk perkembangan. Salah satunya adalah dengan metode bermain peran atau disebut juga pura-pura, fantasi, imajinasi serta drama misalnya menjadi dokter, perawat, pasien, penjaga toko atau pembeli. Hal ini bukan tanpa makna, banyak manfaat yang diperoleh dari salah satunya adalah untuk meningkatkan serta mengembangkan rasa percaya diri.
Berdasarkan permasalahan diatas peneliti tertarik untuk melakukan penelitian dengan judul "Pengaruh Metode Bermain Peran terhadap Peningkatan Percaya Diri pada Anak Usia Pra Sekolah (4-5 tahun) di Pendidikan Anak Usia Dini Insan Harapan Klaten

\section{METODE PENELITIAN}

Penelitian tentang pengaruh
metode bermain peran terahadap peningkatan percaya diri ini merupakan jenis Pra eksperimen design dengan rancangan one group pretest-posttest. Penelitian dilaksanakan di PAUD Insan Harapan Klaten. Waktu penelitian dilaksanakan pada bulan JanuariFebruari 2017.

Sampel dalam penelitian ini yang diambil adalah anak usia pra sekolah yang berumur 4-5 tahun di sekolah Insan Harapan Klaten dengan jumlah 20 anak. Pada penelitian ini, peneliti akan melakukan pengambilan sampel dengan menentukan kriteria inklusi dan eksklusi. Selanjutnya pengambilan sampel ditentukan secara Total Sampling. Analisis data pada penelitian ini adalah menggunakan uji Wilcoxon.

\section{HASIL PENELITIAN}

\section{A. Karakteristik Responden}

Tabel 1 Distribusi frekuensi menurut jenis kelamin responden

\begin{tabular}{lcc}
\hline Jenis Kelamin & Frek & $\%$ \\
\hline Laki-laki & 4 & $20.0 \%$ \\
Perempuan & 16 & $80.0 \%$ \\
Total $(\mathrm{n})$ & 20 & $100 \%$
\end{tabular}


Tabel 2 Distribusi frekuensi berdasarkan tingkat percaya diri sebelum tindakan metode bermain peran

\begin{tabular}{lcc}
\hline Jenis Kelamin & Frek & $\%$ \\
& & \\
\hline Laki-laki & 4 & $20.0 \%$ \\
Perempuan & 16 & $80.0 \%$ \\
Total $(\mathrm{n})$ & 20 & $100 \%$
\end{tabular}

Tabel 3 Distribusi frekuensi berdasarkan tingkat percaya diri sesudah tindakan metode bermain peran

\begin{tabular}{lcc}
\hline Jenis Kelamin & Frek & $\%$ \\
& & \\
\hline Laki-laki & 8 & $40.0 \%$ \\
Perempuan & 12 & $60.0 \%$ \\
Total $(\mathrm{n})$ & 20 & $100 \%$
\end{tabular}

\section{Uji statistik}

Hasil tes statistik uji Wilcoxon diperoleh nilai $0,001(p<0,05)$. Hal ini menunjukan bahwa terdapat perbedaan antara sebelum dan sesuah bermain peran.

\section{B. Karakteristik Anak}

Diawali skrinning dari jumlah 50 orang, laki-laki 28 dan perempuan 22 , didapatkan 20 anak dengan jumlah perempuan 16 orang dan laki-laki berjumlah 4 orang.

Middlebroo dalam penelitian

(Rosita H, 2007) Laki-laki maupun perempuan memiliki efek terhadap perkembangan rasa percaya diri. Perempuan cenderung dianggap lemah dan harus dilindungi, sedangkan laki-laki harus bersikap sebagai makhluk kuat, mandiri dan mampu melindungi.

$$
\text { Hasil analisis karakteristik }
$$
menurut umur responden dalam penelitian ini adalah 4 sampai 5 tahun. Pada usia tersebut akan mengalami pertumbuhan dan perkembangan fisik, kecerdasan, sosio emosional, bahasa dan komunikasi. Pembentukan kepribadian sangatlah penting dalam perkembangan inteligensi diantaranya masa peka, egosentris, berkelompok, meniru, eksplorasi.

Menurut (Hurlock, 2002) dalam penelitian Astuti P.P (2015), pada masa lima tahun pertama yang disebut dengan Golden Period merupakan masa emas bagi perkembangan. Pada usia tersebut, anak mempunyai potensi yang sangat besar untuk mengoptimalkan segala aspek perkembangannya, termasuk perkembangan keterampilan.

Pada penelitian Alfiya S (2015), Usia dini atau awal masa kanak-kanak berlangsung pada periode usia 2 tahun sampai 5 atau 6 tahun. Havinghurst (dalam Hurlock, 1980) menyatakan bahwa perkembangan pada awal akan memengaruhi perkembangan berikutnya, sehingga apabila mengalami kegagalan dalam perkembangan, maka anak akan mengalami kesulitan dalam menjalankan tugas selanjutnya.

Riset cognitive neuroscience (Rushton S, 2011) menunjukkan bahwa sistem neurologis berkembang sangat pesat selama masa awal kanak-kanak dan otak sangat responssif terhadap stimulasi. Berdasarkan hal tersebut diperlukan stimulasi atau rangsangan untuk memfasilitasi agar perkembangannya optimal sehingga masa kanak-kanak harus dimanfaatkan sebaik-baiknya. Stimulasi yang tepat pada masa usia dini akan menentukan kemampuan mereka pada periodeperiode selanjutnya hingga masa dewasa.

Menurut Handayani T.U.N (2014) Anak-anak yang mengikuti PAUD menjadi lebih mandiri, disiplin, dan mudah diarahkan untuk menyerap ilmu pengetahuan secara optimal. Melalui pendidikan usia dini guru dapat memberikan suatu kegiatan untuk mengoptimalkan perkembangan potensi dan kecakapan anak, sebagai salah satu 
modal untuk mencapai kemajuan bangsa yang sekaligus meningkatkan harkat martabat manusia. Keberhasilan pendidikan terutama pendidikan formal salah satunya ditentukan oleh keberhasilan pelaksanaan kegiatan belajar mengajar yaitu dengan cara menumbuhkan kepercayaan diri siswa.

\section{Tingkat percaya diri pada anak sebelum dilakukan metode bermain peran}

Setelah dilakukan observasi pretest Pada tanggal 11 Januari 2017 pukul 07.30 - 10.00 WIB dilakukan pada 6 responden, tanggal 12 Januari 2017 pada 7 responden, dan tanggal 13 Januari 2017 pada 7 responden, didapatkan hasil bahwa dari 20 anak sebanyak 19 anak (95\%) memiliki percaya diri sedang $26-50 \%$ dan 1 anak $(5 \%)$ memiliki percaya diri tinggi $51-75 \%$ sebelum dilakukan tindakan bermain peran. Tiga anak ditunjuk oleh peneliti memperkenalkan diri ada anak merasa gugup, diam saja, tidak memiliki keberanian diri atau kepercayaan diri untuk melakukan perintah yang diberikan.

Penelitian yang dilakukan Prawistri H (2013) kriteria rentang kepercayaan diri dibagi menjadi 4 yaitu, sangat tinggi $76 \%$ - $100 \%$, tinggi $51 \%$ $75 \%$, sedang $26 \%$ - $50 \%$, rendah $0 \%$ $25 \%$. Penelitian menggunakan lembar observasi kepercayaan diri dengan prepost untuk mengetahui tingkat kepercayaan diri.

Dalam penelitian Partini (2015), Kepercayaan diri dapat dipengaruhi oleh faktor internal dan eksternal. Faktor internal meliputi konsep diri yang diperoleh dari pergaulan dalam suatu kelompok, harga diri tentang dirinya sendiri, dan yang paling terpenting adalah kondisi fisik. Faktor eksternal meliputi pola asuh orang tua dan lingkungan. Menurut Madyawati (2016) dalam penelitian Rumilasari N.P.D (2016) manfaat metode bermain peran (role playing) dalam perkembangan yaitu, pertama membangun kepercayaan diri melalui berpura-pura menjadi peran yang diinginkan, dapat membuat anak merasakan sensasi menjadi karakterkarakter yang diperankan sehingga kepercayaan diri meningkat. Kedua mengembangkan kemampuan berbahasa, dimana saat bermain peran anak akan berbicara seperti karakter atau orang yang diperankannya. Hal ini dapat memperluas kosa kata yang dimiliki. Membantu dalam mengulangi dialog yang pernah didengar membuat anak percaya diri dalam berkomunikasi dan mengekspresikan diri, meningkatkan kreativitas dan akal sehingga, memiliki akal yang banyak untuk mencoba membangun dunia impiannya.

Menurut Komara I.B (2016), kepercayaan diri merupakan aspek kepribadian yang berisi keyakinan tentang kekuatan, kemampuan dan keterampilan yang dimilikinya. Seseorang yang memiliki kepercayaan diri biasanya menganggap bahwa dirinya mampu melakukan segala sesuatu yang dihadapinya dengan kemampuan yang dimilik serta merupakan salah satu ciri kepribadian yang mengandung arti keyakinan terhadap kemampuan diri sendiri.

\section{Tingkat percaya diri pada anak setelah dilakukan metode bermain peran}

Post test dilakukan pada tanggal 7 Februari 2017 pukul 07.30 - 10.00 WIB dilakukan pada 6 responden, tanggal 8 Februari 2017 pukul 07.30 - 10.00 WIB pada 7 responden, dan terakhir pada tanggal 9 Februari 2017 pukul 07.30 - 
10.00 WIB pada 7 responden. Setelah selesai kegiatan permainan peran ketiga dengan melakukan evaluasi terkait kegiatan yang telah dilaksanakan.

Hasil pengamatan terhadap permainan peran yang telah diberikan selama 3 kali menunjukkan bahwa yang memilki percaya diri tinggi $51-75 \%$ bertambah menjadi $12(60 \%)$ anak dan dengan percaya diri sedang $26-50 \%$ sedang berkurang menjadi 8 anak (40\%) setelah dilakukan tindakan.

Menurut Rachmawati A (2014), bermain peran adalah salah satu alat belajar yang mengembangkan ketrampilan dan pengertian mengenai hubungan antara manusia dengan jalan memerankan situasi yang parallel dengan yang terjadi dalam kehidupan yang sebenarnya. Bermain peran akan sejalan dengan timbulnya kemampuan untuk berfikir simbolik, yaitu melalui bermain peran akan tumbuh rasa percaya diri dalam diri dengan mengenal bentuk-bentuk emosi, menghayati diri sendiri dan orang lain serta memahami kelebihan dan kekurangan yang ada pada dirinya (Utami S, 2013). Penelitian yang dilakukan Yuliarti A (2015), semua anak usia dini tanpa memandang usia mereka belajar dengan sangat baik melalui bermain. Dalam bermain, anak membuat pilihan, memecahkan masalah, berkomunikasi, dan bernegosiasi. Mereka menciptakan peristiwa khayalan, melatih keterampilan fisik, sosial, dan kognitif. Saat bermain dapat mengekspresikan dan melatih emosi dari pengalaman dan kejadian yang mereka temui setiap hari. Melalui main bersama dan mengambil peran berbeda, untuk mengembangkan kemampuan melihat sesuatu dari sudut pandang orang lain dan terlibat dalam perilaku pemimpin atau pengikut perilaku yang akan diperlukannya saat bergaul ketika dewasa.

\section{KESIMPULAN}

Berdasarkan hasil penelitian dan pembahasan yang telah diuraikan maka dapat ditarik kesimpulan bahwa tingkat percaya diri sebelum dilakukan metode bermain peran didapatkan hasil bahwa, 19 anak (95\%) memiliki percaya diri sedang $26-50 \%$ dan 1 anak (5\%) memiliki percaya diri tinggi tinggi $51-75 \%$ sebelum dilakukan tindakan bermain peran.

Proses metode bermain peran dilakukan 3 kali intervensi, intervensi pertama dengan tema tamasya, intervensi kedua dengan tema cita-cita dan intervensi ketiga dengan tema menjadi orang tua. Tingkat percaya diri setelah dilakukan metode bermain peran dapat didapatkan hasil bahwa, menunjukkan bahwa 8 anak $(40 \%)$ memiliki percaya diri sedang $26-50 \%, 12$ anak $(60 \%)$ memiliki percaya diri tinggi $51-75 \%$ sesudah dilakukan tindakan.

Terdapat peningkatan rata-rata percaya diri anak sesudah dilakukan terapi bermain peran. Rata rata sebelum bermain peran adalah 31.25 , tingkat percaya diri terendah 27.50 dan tertinggi 48.75. Rata-rata tingkat percaya diri anak setelah dilakukan bermain peran yaitu 53.75 , tingkat percaya diri terendah 46.25 sedangkan tingkat percaya diri tertinggi 71.25. Terdapat peningkatan mean skor kepercayaan diri meningkat menjadi $18.44 \%$ antara mean sebelum dilakukan bermain peran $37.31 \%$ dan setelah dilakukan bermain peran sebesar $55.75 \%$.

Hasil tes statistik uji Wilcoxon diperoleh nilai $0,001 \quad(p<0,05)$, hal ini menunjukan ada perbedaan antara tingkat percaya diri sebelum dan sesudah dilakukan bermain peran. Maka 
HO yang menyatakan "bermain peran tidak berpengaruh terhadap peningkatan percaya diri pada anak usia pra sekolah (4-5 tahun) pendidikan anak usia dini di Insan Harapan Klaten" ditolak, $\mathrm{H} 1$ yang menyatakan "bermain peran berpengaruh terhadap peningkatan percaya diri pada anak usia pra sekolah (4-5 tahun) pendidikan anak usia dini di Insan Harapan Klaten diterima. Hal tersebut menunjukkan bahwa metode bermain peran berpengaruh terhadap tingkat percaya diri sebelum dilakukan metode bermain peran dengan sesudah dilakukan metode bermain peran.

\section{SARAN}

Berdasarkan hasil penelitian yang telah dilaksanakan, saran yang dapat peneliti berikan bagi Penyelenggara PAUD Insan Harapan Klaten yaitu melatih percaya diri pada anak dengan melakukan hafalan suratsurat pendek, melakukan praktik sholat dan bacaaan sholat satu persatu di depan kelas.

Bagi peneliti selanjutnya, perlu dilakukan penelitian lebih lanjut dengan menggunakan kelompok kontrol pada penelitian sehingga dapat membandingkan antara kelompok kontrol maupun kelompok eksperimen. Menggunakan variabel yang berbeda untuk penelitian yang akan datang.

\section{DAFTAR PUSTAKA}

Alfiyah S. Validasi Modul Bermain Peran "Aku Sayang Kawan" untuk Meningkatkan Pengetahuan Perilaku Prososial pada Anak Usia Dini. $\quad$ 2015.1;120 - 137

Arikunto, S. Prosedur Penelitian Suatu Pendekatan Praktek. Jakarta. Rineka Cipta; 2006

Astuti. P. P. Efektivitas Metode Bermain

$\begin{array}{ll}\text { Peran (Role Play) untuk } \\ \text { Meningkatkan } & \text { Keterampilan } \\ \text { Komunikasi Pada Anak. } 2015\end{array}$

Babakal, A. Pengaruh Alat Permainan Edukatif Terhadap Aspek Perkembangan Pada Anak Pra Sekolah Di Wilayah Puskesmas Ondong Kabupaten Kepulauan Siau Tagulandang Biaro; 2013.pp.16-20.

Diana Ariswanti Triningtyas. Meningkatkan Rasa Percaya Diri Anak Melalui Terapi Bermain. 2011.

Dian Adriana. Tumbuh Kembang dan Terapi Bermain pada Anak. Jakarta. Salemba Medika; 2013

Diana Mutiah. Psikologi Bermain Anak Usia Dini. Jakarta: Prenada Media Group; 2015.

Handayani T. U. N Upaya Meningkatkan Kepercayaan Diri Dengan Metode Bercerita Menggunakan Wayang Kardus Pada Anak

Hermayanti T, Peningkatan Kepercayaan Diri Melalui Kegiatan Menari Kreatif, 2015.

Hodijah S. Upaya Meningkatkan Keterampilan Berbicara Anak Melalui Metode Bermain Peran. 2015

Janice J. Beauty. Observasi Perkembangan Anak Usia Dini 7th ed. Jakarta. Kencana Prenadamedia Group; 2014.

Jasa Ungguh Muliawan. Tips Jitu Memilih Mainan Positif dan Kreatif untuk Anak Anda. Yogyakarta. Diva Press; 2009.

Khodijah, S.R Optimalisasi Metode Bermain Peran dengan Menggunakan Alat 
Permainan Edukatif Dalam Mengasah Percaya Diri Anak Usia Dini.2012

Komara. I. B. Hubungan antara Kepercayaan Diri dengan Prestasi Belajar dan Perencanaan Karir Siswa. 2016

M. Sopiyudin Dahlan. Statistik untuk Kedokteran dan Kesehatan (6th ed.). Jakarta. Epidemologi Indonesia; 2014.

Notoatmodjo, S. Metodologi Penelitian Kesehatan. Edisi Revisi. Jakarta. Rineka Cipta; 2010.

Novan Ardy Wiyani, M. P. Konsep Dasar PAUD. Yogyakarta. Gava Media; 2016.

Nursalam. Konsep dan Penerapan Metodologi Penelitian IImu Keperawatan. Jakarta. Salemba Medika; 2009.

Nurul Aida dan Rr Amanda Pasca Rini. Penerapan Metode Bermain Peran untuk Meningkatkan

Kemampuan Bersosialisasi pada Pendidikan Anak Usia Dini. 2015. 4; 87 - 99

Obidike. The Role of Teachers of Young Children in ensuring Developmentally Appropriate Practice in Early Childhood Education Curriculum Implementation. 2013.4 (5); 821826.

Pratiwi, E. S. Perbedaan Pengaruh Terapi Bermain Mewarnai Gambar dengan Bermain Puzzle Terhadap Kecemasan Anak Usia. 2013; $16-$ 20.

Prawistri H. Upaya Meningkatkan Rasa Percaya Diri Anak Kelompok B Melalui Kegiatan Bermain Aktif
Di Tk Pembina Kecamatan Bantul. 2013

Puspitasari, R. D. H. dan N. P. D. Pengaruh terapi bermain terhadap tingkat kooperatif selama menjalani perawatan pada anak usia pra sekolah ( $3-5$ tahun) di rumah sakit panti rapih yogyakarta. 2008 .

Rachmawati A. Pengaruh Metode Bermain Peran Terhadap Perkembangan Sosisal Emosional Anak di RA Nurul Ihsan Kecamatan Mojosongo Kabupaten Boyolali Tahun 2013/2014

Rawania. Optimalisasi Metode Bermain Peran denganMenggunakan Alat Permainan Edukatif dalam Mengasah Percaya Diri Anak Usia Dini.2015

Rosita H. Hubungan Antara Perilaku Asertif dengan Kepercayaan Diri Pada Mahasiswa;2007

Rumilasari. N.P.D. Pengaruh Metode Bermain Peran (Role Playing) Terhadap Kemampuan Berbicara Pada Anak Kelompok A. 2016; 4.

Rushton S. Neuroscience, Early Childhood Education and Play: We are Doing it Right!.2011

Sri Esti Wuryani Djiwandono. Konseling dan Terapi dengan Anak dan Orang Tua. Jakarta. Gramedia Widiasarana Indonesia; 2005.

Sri Ratna Chodijah.Metode Bermain Peran dalam Mengembangkan Sosial, Emosional, dan Kemandirian Anak Usia Dini. 2012; 59-69.

Utami S, Pengaruh Bermain Peran Terhadap Kepercayaan Diri Pada Anak Di TK Khusnul Khotimah 
Semarang, 2013.

Sugiyono. Statistik Untuk Penelitian. Bandung. Alfabeta; 2010

Sundari. Peningkatan Rasa Percaya Diri melalui Bermain Peran pada Anak Kelompok B di TK Pertiwi 03 Tambak Mojosongo boyolali tahun 2012/2013

Uno, Hamzah.B. Perencanaan Pembelajaran. Jakarta, Bumi Aksara; 2009

V. Wiratna Sujarweni. Metodologi Penelitian Keperawatan. Yogyakarta. Gava Media; 2014.

Wasis. Pedoman Riset Praktis untuk
Profesi Perawat. Jakarta. EGC; 2008.

Winarni, R. Kepercayaan Diri Dengan Kecemasan Komunikasi Di Depan Umum pada Mahasiswa.2013.1

Yuliarti A. Analisis Pembelajaran Bermain Peran Terhadap Perkembangan Komunikasi Anak Usia 4 - 5 Tahun Di Paud Melati 1 Tahun Ajaran 2015/2016

Yuslam Sungkar dan Pratiwi. Sense Of Humor Sebagai Langkah Meningkatkan Kepercayaan Diri Guru PPL Dalam Proses Belajar Mengajar,

2013. 